\title{
DAMAGE TO REINFORCED CONCRETE BUILDINGS AND COASTAL TREES DUE TO THE 2011 OFF THE PACIFIC COAST OF TOHOKU EARTHQUAKE TSUNAMI
}

\author{
Hideo Matsutomi', Eriko Yamaguchi ${ }^{2}$, Kazunori Naoe $^{3}$ and Kenji Harada ${ }^{4}$
}

\begin{abstract}
Macroscopic conditions of the damage to RC building and coastal black pine tree in the 2011 Off the Pacific Coast of Tohoku Earthquake Tsunami are discussed through field surveys and field tests. Effects of RC building's location and arrangement, submerged vertical section area in the tsunami inundation flow direction, ratio of the area of submerged windows and/or doorways to the area of submerged vertical wall on the side hit by the inundation flow (so-called, aperture ratio), and foundation piles on the damage condition of the building are examined. The damage condition of the coastal tree is also discussed from the viewpoints of the drag force and moment assessed using inundation flow velocity estimated by a simple method. Moreover, effects and limits of coastal woods on the tsunami energy and force reductions are illustrated through the field surveys.
\end{abstract}

Keywords: the 2011 off the Pacific Coast of Tohoku Earthquake Tsunami; field survey; field test: reinforced concrete building; coastal woods

\section{INTRODUCTION}

At 05:46 GMT (14:46 local time at the epicenter), March 11, 2011, the 2011 Off the Pacific Coast of Tohoku Earthquake (the 2011 Tohoku Earthquake for short) with $M_{w} 9.0$ [JMA, 2011] occurred off the east coast of the northern Honshu Island, Japan $\left(37^{\circ} 49^{\prime} \mathrm{N}, 143^{\circ} 03^{\prime} \mathrm{E}\right)$ (see Fig. 1) and generated a huge tsunami with $M_{t} 9.1$ [Abe, 2011]. Earthquakes with $M_{w} \geq 9.0$ had not occurred in Japan including this region at least for the last 1,400 years in documents. The tsunami mainly struck the east coast of the northern Honshu Island, and heavily damaged lives, properties, buildings and infrastructures like the 2004 Indian Ocean Tsunami. The numbers of the dead and missing have reached 15,781 and 7,336 respectively, as of September 10, 2011.

One of the features of the 2011 Tohoku Earthquake Tsunami is that a huge tsunami attacked many modern cities. As the results, the tsunami moved and/or toppled several reinforced concrete (RC for short) buildings whose height and depth were not enough for tsunami inundation depth (see Fig. 2). Since the 1933 Showa Sanriku Earthquake Tsunami, there has been an idea of RC building which has the role as a coastal dyke and is usually used as public facilities or private offices. This building has not only a function of reducing tsunami inflow into the backland but also that of the short-term tsunami refuge facilities. However, there is no guideline for the condition (depth, width, height, etc.) of the building which withstands tsunami with any inundation depth.

In this tsunami, coastal woods on the Sanriku coast were heavily damaged, but those on the Sendai coast showed a certain measure of effect on the tsunami energy and force reductions. It is necessary to grasp characteristics such as the damage type and damage condition of coastal tree to actively use the coastal woods and accurately estimate the tsunami energy and force reductions due to the coastal woods.

It is unclear what degree the earthquake directly influenced the damage to RC buildings and coastal trees in the tsunami inundation area. In this study, assuming the damage is due to only the tsunami, macroscopic conditions of the damage to RC buildings and coastal black pine trees which are popular in the coastal areas in Japan are discussed through field surveys and field tests in the tsunami inundation area. The damage conditions such as the lodging, uprooting and breaking of coastal black pine tree are also discussed from the viewpoints of the drag force and moment acting on each tree, where those are assessed using inundation flow velocity estimated by the simple method proposed by Matsutomi [2009a]. Moreover, effects and limits of coastal woods on the tsunami energy and force reductions are illustrated through field surveys on the Sendai coast.

\footnotetext{
${ }^{1}$ Department of Civil and Environmental Engineering, Akita University, 1-1 Tegata Gakuen, Akita, 010-8502, Japan ${ }^{2}$ Department of Civil Engineering, Iwate Prefectural Government, 10-1 Uchimaru, Morioka, Iwate, 020-8570, Japan

${ }^{3}$ Department of Civil and Environmental Engineering, Akita University, 1-1 Tegata Gakuen, Akita, 010-8502, Japan

${ }^{4}$ Center for Integrated Research and Education of Natural Hazards, Shizuoka University, 836 Ohya, Suruga, Shizuoka, 422-8529, Japan
} 


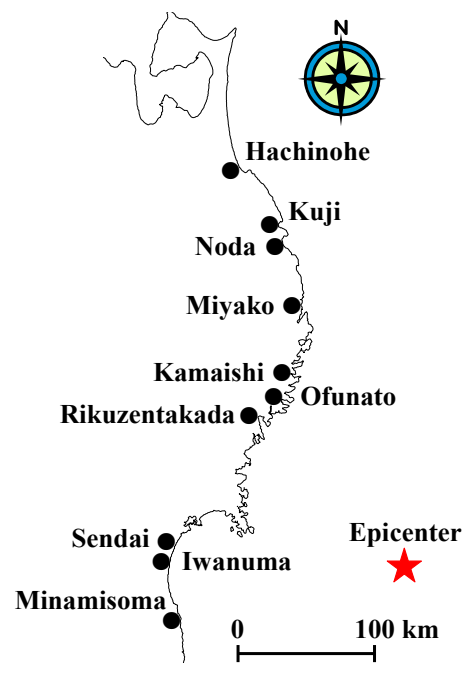

Figure 1. Field survey areas on the east coast of the northern Honshu Island, Japan.

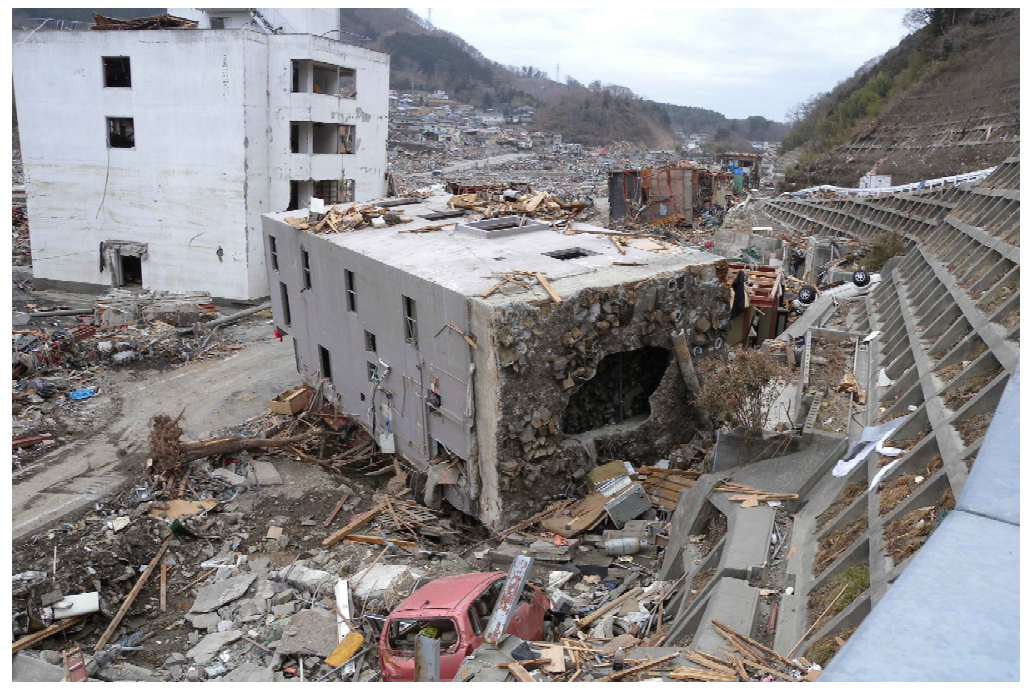

Figure 2. A 4-story RC building (7.0 m wide, $5.3 \mathrm{~m}$ deep and $13.3 \mathrm{~m}$ high) swept away about $70 \mathrm{~m}$ together with foundation piles of the friction type by the 2011 Tohoku Earthquake Tsunami (Onagawa in Miyagi pref.).

\section{FIELD SURVEYS AND FIELD TESTS}

\section{Field Surveys}

Field surveys of the damage to buildings were carried out mainly for RC buildings with 2 stories and over from the Kuji coast in Iwate pref. to the Minamisoma coast in Fukushima pref. from March 26 to Nov. 25, 2011. The survey areas are shown in Fig. 1. Major points of the field surveys were 1) location and arrangement, 2) structure classification (S.C. for short), 3) dimensions (depth, width, height), 4) area of windows and/or doorways, 5) depth of foundation part under the ground, 6) foundation piles, 7) surrounding pavement, 8) inundation depth, 9) damage type of building, 10) ground height and 11) liquefaction of the ground. Some of the collected data are shown in Table 1.

Except for the inclined RC buildings due to the ground erosion, there were 7 moved and/or toppled $\mathrm{RC}$ buildings, listed in Table 2 . The building symbolized (e) was moved landwards and toppled on the sea side. The building (f) was moved seawards and toppled on the sea side. Others were moved landwards and/or toppled on the land side. The buildings (a), (b), (e), (f) do not have foundation piles, but the buildings (c), (d), (g) have them.

Field surveys of the damage to coastal black pine trees were carried out in parallel with those of the damage to buildings. Major points of the field surveys were 1) chest height diameter of tree trunk, 2) inundation depth, 3) damage type of tree, 4) tree density of coastal woods and 5) ground height. 
COASTAL ENGINEERING 2012

Table 1. Data set of buildings damaged by the 2011 Tohoku Earthquake Tsunami.

\begin{tabular}{|c|c|c|c|c|c|c|c|c|c|}
\hline Place & S.C. & $\begin{array}{l}\text { No. of } \\
\text { Stories }\end{array}$ & $\begin{array}{l}\text { G.H. } \\
(\mathrm{m})\end{array}$ & $\begin{array}{l}\text { Width } \\
(\mathrm{m})\end{array}$ & $\begin{array}{c}\text { Depth } \\
(\mathrm{m})\end{array}$ & $\begin{array}{l}\text { Height } \\
(\mathrm{m})\end{array}$ & $\begin{array}{l}\text { Inundation } \\
\text { Depth }(\mathrm{m})\end{array}$ & Use & $\begin{array}{c}\text { Damage } \\
\text { Type }\end{array}$ \\
\hline Tsugaruishi & Block & 2 & 2.81 & 21.4 & 6.4 & 6.1 & $9.01 \mathrm{R}$ & Condominium & $M \& T$ \\
\hline Tsugaruishi & Block & 2 & 2.81 & 17.0 & 6.4 & 6.1 & $9.01 \mathrm{R}$ & Condominium & $M \& T$ \\
\hline Ohtsuchi & $\mathrm{RC}$ & 3 & 1.16 & 11.9 & 7.5 & 8.3 & 8.99 & Condominium & W \\
\hline Ohtsuchi & $\mathrm{RC}$ & 2 & - & 6.7 & 6.3 & 5.7 & 8.99 & Private house & $M \& T$ \\
\hline Rikuzentakata & $\mathrm{RC}$ & 5 & 1.75 & 68.4 & 7.1 & 14.7 & 11.41 & Condominium & W \\
\hline Rikuzentakata & $\mathrm{RC}$ & 5 & 1.87 & 68.3 & 7.1 & 14.7 & 11.57 & Condominium & $\mathrm{W}$ \\
\hline Rikuzentakata & $\mathrm{RC}$ & 3 & 0.65 & 20.2 & 8.3 & 8.4 & 11.57 & Condominium & W \\
\hline Rikuzentakata & $\mathrm{RC}$ & 3 & - & 7.3 & 6.8 & 8.6 & 10.22 & Private house & $M \& T$ \\
\hline Shizugwa & $\mathrm{RC}$ & 3 & 0.93 & 18.5 & 13.1 & 11.4 & 12.99 & Public hall & $\mathrm{D}$ \\
\hline Shizugwa & $\mathrm{RC}$ & 3 & -0.08 & 9.5 & 12.4 & 10.7 & 12.99 & Office & W \\
\hline Tokura & $\mathrm{RC}$ & 2 & 0.83 & 19.0 & 10.5 & 8.4 & $>8.44$ & Public hall & Inclined \\
\hline Onagawa & $\mathrm{RC}$ & 3 & 0.11 & 11.8 & 6.7 & 10.4 & 11.02 & Store & $M \& T$ \\
\hline Onagawa & $S$ & 3 & 0.35 & 15.5 & 8.1 & 12.3 & 14.36 & Office & $M \& T$ \\
\hline Onagawa & $\mathrm{RC}$ & 5 & 0.08 & 13.8 & 6.8 & 17.2 & 14.63 & Inn & W \\
\hline Onagawa & $\mathrm{RC}$ & 4 & 0.08 & 7.0 & 5.3 & 13.3 & 14.63 & Inn & $M \& T$ \\
\hline Onagawa & $\mathrm{RC}$ & 2 & 0.08 & 23.4 & 9.0 & 9.0 & 14.63 & Cold store & $M \& T$ \\
\hline Onagawa & $\mathrm{RC}$ & 2 & 0.22 & 10.7 & 5.0 & 6.0 & 11.02 & Police station & $M \& T$ \\
\hline Onagawa & $\mathrm{RC}$ & 3 & 0.22 & 29.8 & 5.9 & 9.3 & 11.02 & Condominium & $M \& T$ \\
\hline Ishinomaki & $\mathrm{RC}$ & 4 & 0.61 & 50.5 & 7.7 & 11.8 & 6.67 & Condominium & W \\
\hline Ishinomaki & $\mathrm{RC}$ & 4 & 0.37 & 52.9 & 7.2 & 12.3 & 5.93 & Condominium & W \\
\hline Yamada & $\mathrm{RC}$ & 2 & 1.15 & 8.9 & 8.6 & 7.1 & 5.40 & Private house & Inclined \\
\hline Yamada & Block & 2 & 0.96 & 11.3 & 5.6 & 5.8 & 6.63 & Condominium & $M \& T$ \\
\hline Ohtsuchi & Block & 2 & 0.48 & 16.3 & 6.4 & 6.5 & 11.14 & Condominium & $M \& T$ \\
\hline Ohtsuchi & Block & 2 & 0.56 & 23.9 & 6.5 & 5.7 & 11.06 & Condominium & W \\
\hline Nehama & $\mathrm{RC}$ & 3 & 2.16 & 14.8 & 14.0 & 10.6 & 11.92 & Rest house & Inclined \\
\hline Kesennuma & $\mathrm{RC}$ & 2 & 0.86 & 27.3 & 10.1 & 9.0 & 8.47 & Waste oil plant & Inclined \\
\hline Kesennuma & $\mathrm{RC}$ & - & - & 15.8 & 19.5 & 9.5 & 7.03 & Pumping station & PD \\
\hline Gamou (Sendai) & $\mathrm{RC}$ & - & - & 51.1 & 30.3 & 13.3 & 7.3 & Pumping station & PD \\
\hline Gamou (Sendai) & $\mathrm{RC}$ & - & 2.21 & 27.8 & 7.9 & 11.3 & 8.1 & Pumping station & PD \\
\hline Yamada & Block & 2 & 1.20 & 6.4 & 13.8 & 6.1 & 4.92 & Private house & Inclined \\
\hline Ohfunato & $\mathrm{RC}$ & 2 & 1.79 & 12.2 & 11.4 & 7.2 & 7.04 & Store & W \\
\hline Rikuzentakata & $\mathrm{RC}$ & 2 & - & 41.5 & 6.6 & 6.7 & - & Youth hostel & Inclined \\
\hline Kesencho & $\mathrm{RC}$ & 3 & 3.07 & 21.7 & 10.9 & 8.5 & 8.57 & Condominium & W \\
\hline Shizugwa & $\mathrm{RC}$ & 4 & 0.35 & 22.2 & 37.9 & 18.9 & 12.99 & Ceremony hall & W \\
\hline Shizugwa & $\mathrm{RC}$ & 5 & 0.35 & 39.2 & 18.8 & 19.3 & 12.27 & Hospital & W \\
\hline Shizugwa & $\mathrm{RC}$ & 4 & 0.35 & 60.5 & 13.2 & 15.3 & 12.81 & Hospital & W \\
\hline Shizugwa & $\mathrm{RC}$ & 3 & 0.35 & 10.0 & 24.0 & 9.1 & 12.81 & Condominium & W \\
\hline Shizugwa & $\mathrm{RC}$ & 4 & 2.87 & 72.9 & 11.0 & 13.5 & 11.07 & Condominium & W \\
\hline Shizugwa & $\mathrm{RC}$ & 2 & - & 6.1 & 16.5 & 7.5 & 11.07 & Meeting place & W \\
\hline Shizugwa & $\mathrm{RC}$ & 3 & 2.59 & 24.4 & 12.6 & 9.7 & 10.9 & Condominium & W \\
\hline Kesennuma & $\mathrm{RC}$ & 3 & - & 16.2 & 8.8 & 8.4 & 9.63 & Condominium & W \\
\hline
\end{tabular}

where S.C.: Structure classification, G.H.: Ground height, R: Run-up height minus ground height, M \& T: Moved and/or toppled, W: Withstood, PD: Partially destroyed, D: Destroyed.

\section{Field Tests}

Field tests on the damage type and damage condition of coastal black pine tree were carried out on the Taro coast located in the north of Miyako (from Dec. 6 to 9, 2011) and on the Yamada coast located between Miyako and Kamaishi (from May 11 to 13 and June 15 to 17, 2012) in Iwate pref. 
Table 2. List of moved and/or toppled building.

\begin{tabular}{|c|c|c|c|}
\hline Place & $\begin{array}{c}\text { No. of } \\
\text { Stories }\end{array}$ & Use & Symbol \\
\hline Ohtsuchi & 2 & Private house & $\mathrm{a}$ \\
\hline Rikuzentakata & 3 & Private house & $\mathrm{b}$ \\
\hline Onagawa & 2 & Cold store & $\mathrm{c}$ \\
\hline Onagawa & 2 & Police station & $\mathrm{d}$ \\
\hline Onagawa & 3 & Condominium & $\mathrm{e}$ \\
\hline Onagawa & 3 & Store & $\mathrm{f}$ \\
\hline Onagawa & 4 & $\mathrm{Inn}$ & $\mathrm{g}$ \\
\hline
\end{tabular}

Major measurement points of the field tests were 1) tree density of coastal woods, 2) tree height, 3) chest height diameter of tree trunk, 4) horizontal force loaded at the chest height (1.2 $\mathrm{m}$ high from the ground) and others (2.4 m, 3.6 m, $4.8 \mathrm{~m}$ high from the ground), 5) horizontal displacement (deflection) at the chest height, 6) specific gravity of the chest height diameter part, 7) dimensions (depth, widths in the two directions crossing at right angles) of root, 8) ground height, 9) ground water level, and soil was collected at each test site. The horizontal force was loaded using wire ropes, a pulley and an excavator, and measured by a load cell (Tokyo Sokki Kenkyujo, capacity $=100 \mathrm{kN}$ or $200 \mathrm{kN}$ ). The horizontal displacement was measured using surveying poles graduated in $10 \mathrm{~cm}$ which were set up close to each test tree and taking a picture every load stage constant distance $(8 \mathrm{~m})$ apart.

\section{MOVING AND/OR TOPPLING CONDITION TO RC BUILDING}

Figure 3 shows a relationship among RC building height $H$, inundation depth $h$ and damage type of the building, where $\bullet$ is the moved and/or toppled with foundation piles, $\boldsymbol{\Delta}$ the moved and/or toppled without foundation piles and $\bigcirc$ the withstood. These legends are the same in the following figures in this section. The solid line in the figure is the dividing line between the submerged and nonsubmergence. The figure indicates that 1) in this tsunami, there were no moved and/or toppled RC buildings with 5-stories and over including the submerged and inclined due to the ground erosion and 2) when Japanese RC buildings were not submerged at the maximum inundation depth of the tsunami, even those designed under the old earthquake-resistant standard before 1981 could withstand.

There were many withstood $\mathrm{RC}$ buildings though a huge tsunami submerged them. It is conceivable as the reasons that the damage to $\mathrm{RC}$ buildings depends on 1) their location and arrangement, 2) the submerged vertical section area $A_{C}$ of the building in the inundation flow direction (see Fig. 4), 3) the ratio $O_{p}$ of the area $A_{D W}$ of submerged windows and/or doorways to the area $A_{t}$ of submerged vertical wall of the building on the side hit by the inundation flow, so-called 'aperture ratio' (see Fig. 5), 4) the easiness of outflow of air from indoor spaces including roof and floor spaces to outside, 5) the depth of foundation part under the ground, 6) with or without foundation piles, 7) with or without pavement around the building, 8) liquefaction of the ground.

Figure 4 shows a relationship among the submerged vertical section area $A_{C}$ of RC building in the inundation flow direction, inundation depth $h$ and damage type of the building. The dotted line in the figure shows the relationship between the submerged vertical section area of the building with the depth $=6.8 \mathrm{~m}$ and inundation depth. The figure indicates that 1) RC building is desirable to have a deeper depth than $6.8 \mathrm{~m}$ to withstand tsunami inundation flows, 2) there is a difference between the inundation depths of damaged building with and without foundation piles, and 3) the submerged vertical section area is a good parameter to judge whether RC buildings are moved and/or toppled. The result 2) is reasonable considering the fact that foundation piles are used when the dead load of building per unit area is large, though depending on the ground condition. For your information, the aperture ratio $O_{p}\left(=A_{D W} / A_{t}\right)$ of the data with the symbol I $(\bigcirc)$ is 0.26 and that of the data with the symbol $\mathrm{f}(\boldsymbol{\Delta})$ is 0.05 (see Fig. 6).

Figure 5 shows an example of relationship among inundation depth $h$ and various submerged areas of the building on the side hit by the inundation flow, where $A_{C W}$ is the area of submerged vertical concrete wall and $A_{t}=A_{C W}+A_{D W}$. The submerged areas are evaluated using the dimensions of building shown in Table 1 and pictures taken from the surroundings of building. 


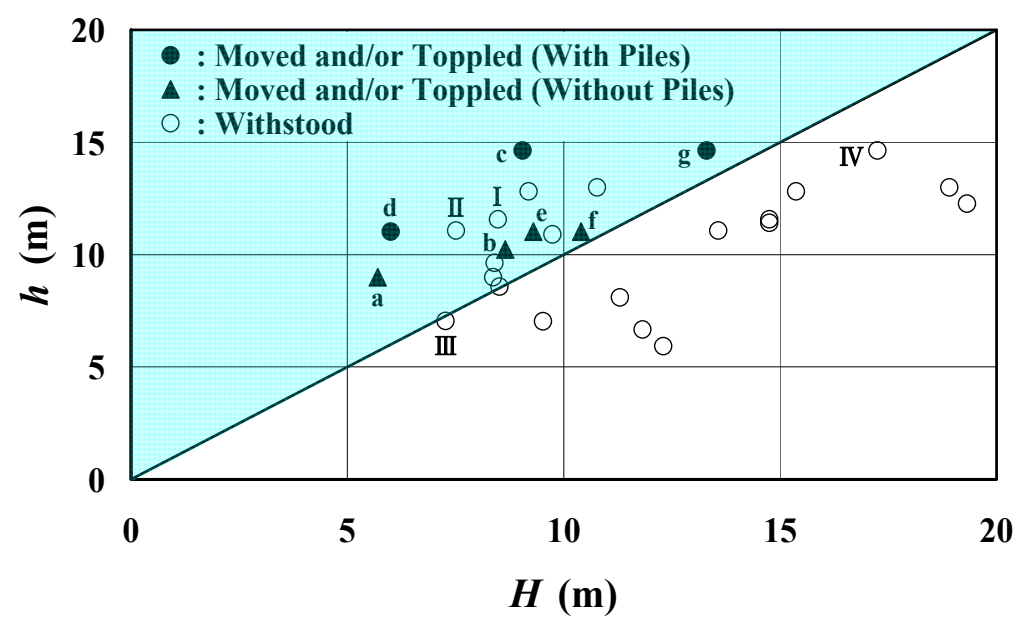

Figure 3. Relationship among RC building height $H$, inundation depth $h$ and damage type of the building.

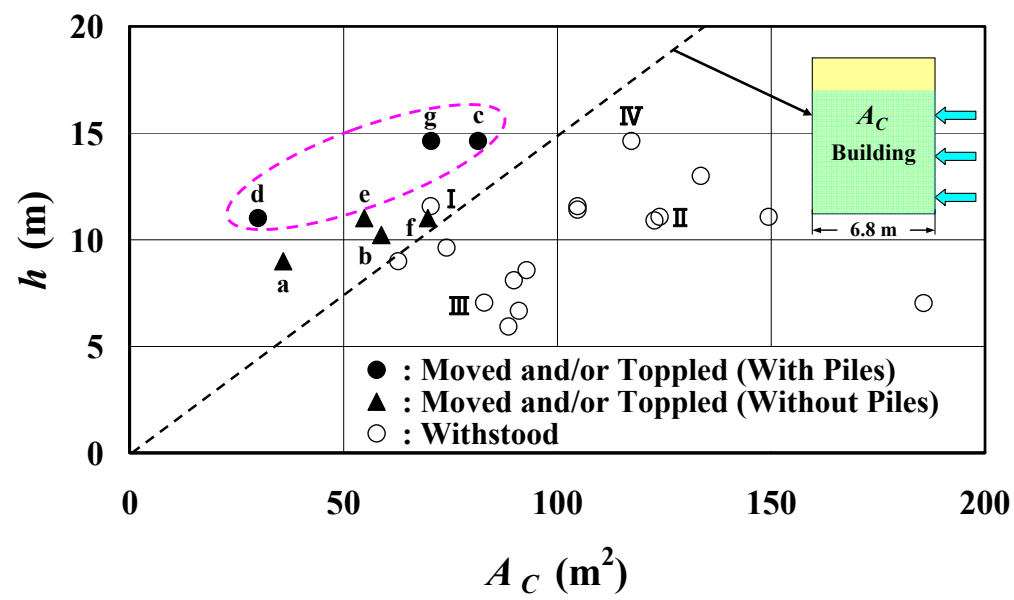

Figure 4. Relationship among the submerged vertical section area $A_{C}$, inundation depth $h$ and damage type of the building.

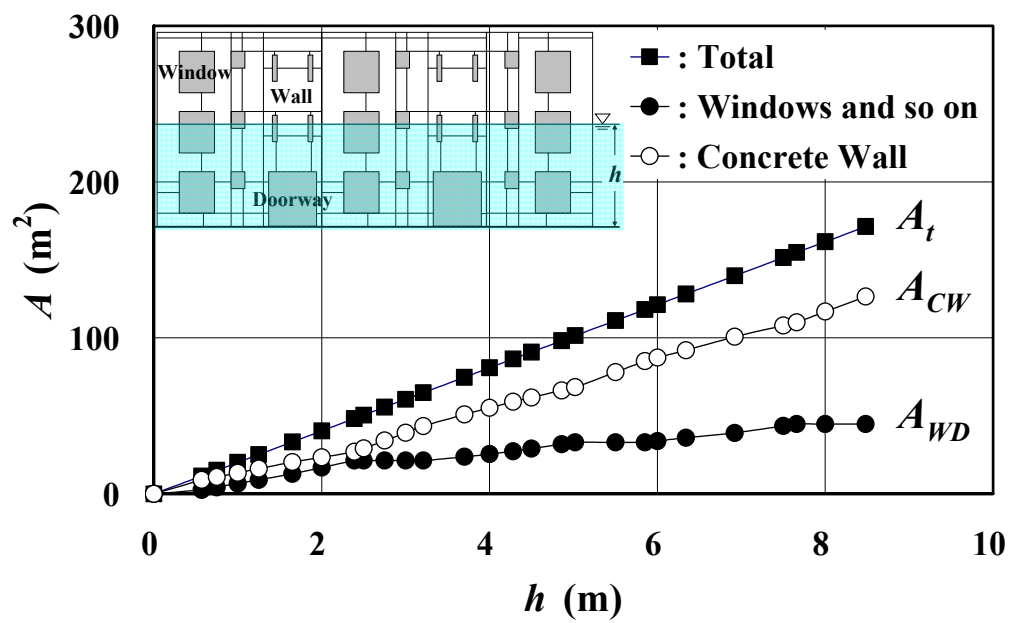

Figure 5. An example of relationship among inundation depth $h$ and various submerged areas on the side hit by the inundation flow (a 3-story RC building in Rikuzentakata, Iwate pref.). 


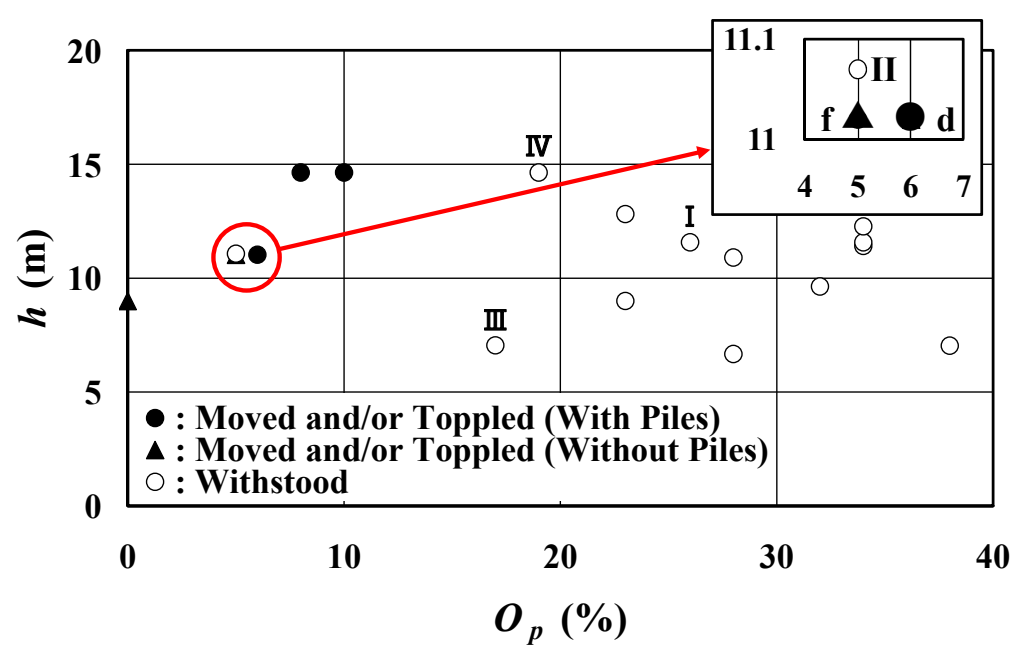

Figure 6. Relationship among the aperture ratio $O_{p}$, inundation depth $h$ and damage type of the building.

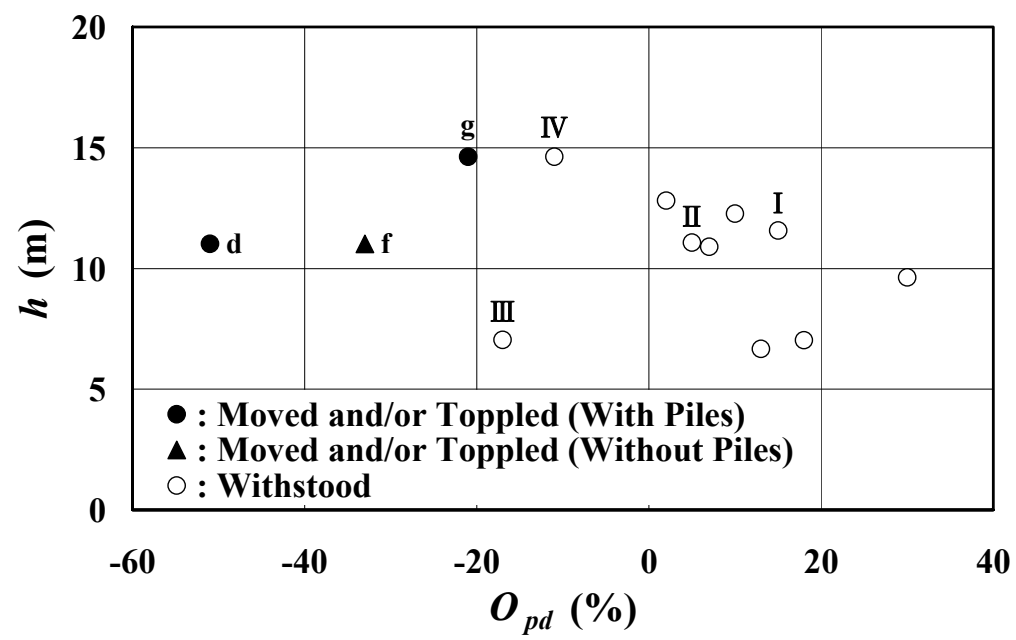

Figure 7. Relationship among the aperture ratio difference $O_{p d}$, inundation depth $h$ and damage type of the building.

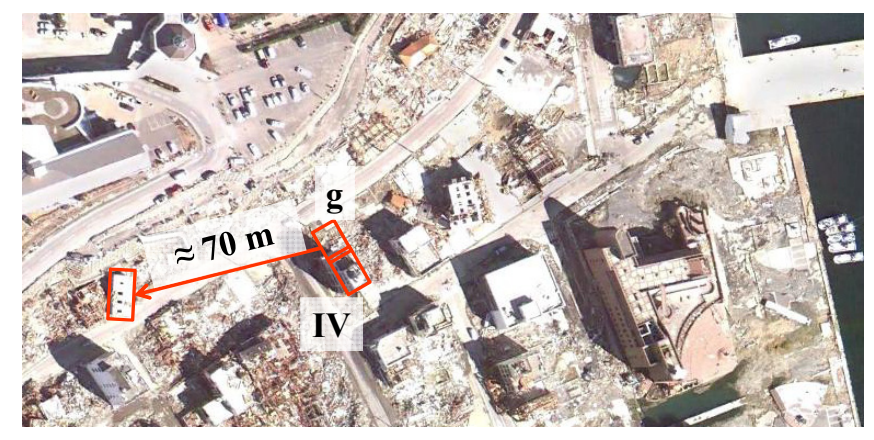

Figure 8. Withstood building (IV) and moved and/or toppled building (g) in Onagawa, Miyagi pref. (Google Earth)

Figure 6 shows a relationship among the aperture ratio $O_{p}$, inundation depth $h$ and damage type of the building. The figure indicates that 1 ) the aperture ratio of actual $\mathrm{RC}$ building is around $38 \%$ at the maximum and 2) the building with a small aperture ratio is easy to move and/or topple, compared with that with a large aperture ratio. There are the withstood building (II) and the moved and/or toppled buildings (d) and (f) in spite of almost the same values of the aperture ratio (5\%) and inundation depth 
(11 m). As will be seen from Fig. 4, the building with a small submerged vertical section area has a tendency to be moved and/or toppled. The building (II) is considered to withstand because it has a larger submerged vertical section area, compared with the buildings (d) and (f). In Fig. 3, the withstood buildings in spite of the submergence have $O_{p}=17-38 \%$ except for the building (II) and the move and/or toppled buildings have $O_{p}=0-10 \%$. The former $O_{p}$ is greater than the latter.

Figure 7 shows a relationship among 'aperture ratio difference' $O_{p d}$, inundation depth $h$ and damage type of the building, where the definition of the aperture ratio difference is $O_{p d}=O_{p}$ on the side hit by the inundation flow $-O_{p}$ on the opposite side. The figure indicates that all $O_{p}$ of the moved and/or toppled building are negative.

There are two withstood buildings (III) and (IV) although their $O_{p d}$ is negative. It is conceivable as the reasons that 1) the building (III) was not submerged because of a relatively shallow inundation depth $(=7.05 \mathrm{~m})$ and had a relatively large aperture ratio $(=0.17), 2)$ the building (IV) with 5 stories was sheltered by many large buildings left on the sea side as shown in Fig. 8. The building (IV) and the moved and toppled building (g) with 4 stories were side by side and had the same inundation depth of $14.6 \mathrm{~m}$. Although both aperture ratios on the land side are 0.29 together, those on the side are the building (IV) is 0.19 and the building (g) 0.08. Besides, as will be seen from Figs. 3 and 4, the height and submerged vertical section area of the building (IV) are larger than those of the building (g).

Figure 9 shows a relationship among the relative depth $h_{B} / H$ of foundation part under the ground, relative inundation depth $h / H$ and damage type of the building. The figure indicates that 1) the depth of foundation part under the ground of actual RC building is around 7-21\% of the building height, 2) even

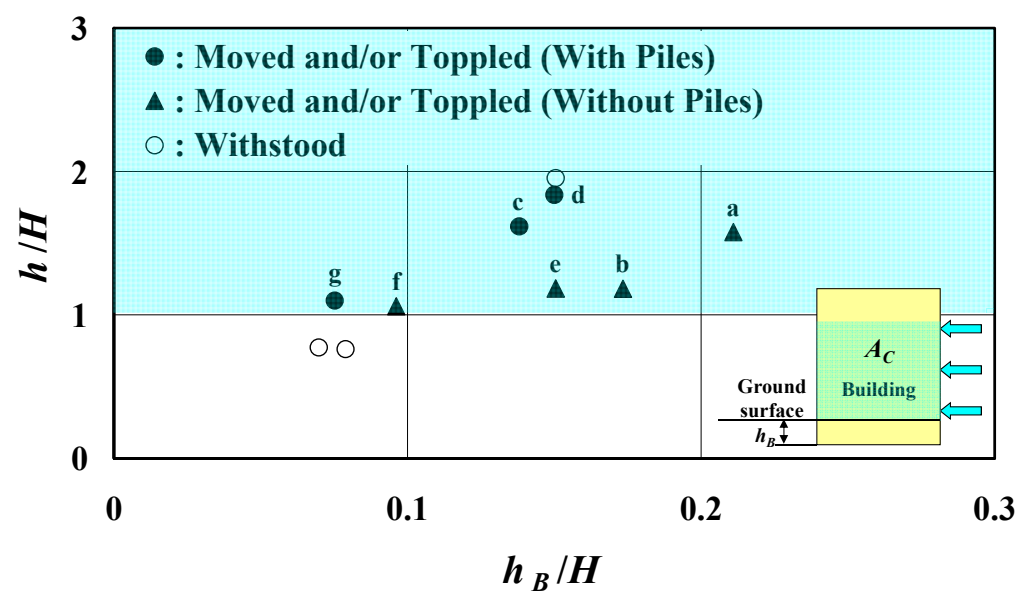

Figure 9. Relationship among the relative depth $h_{B} / H$ of foundation part under the ground, relative inundation depth $h / H$ and damage type of the building.

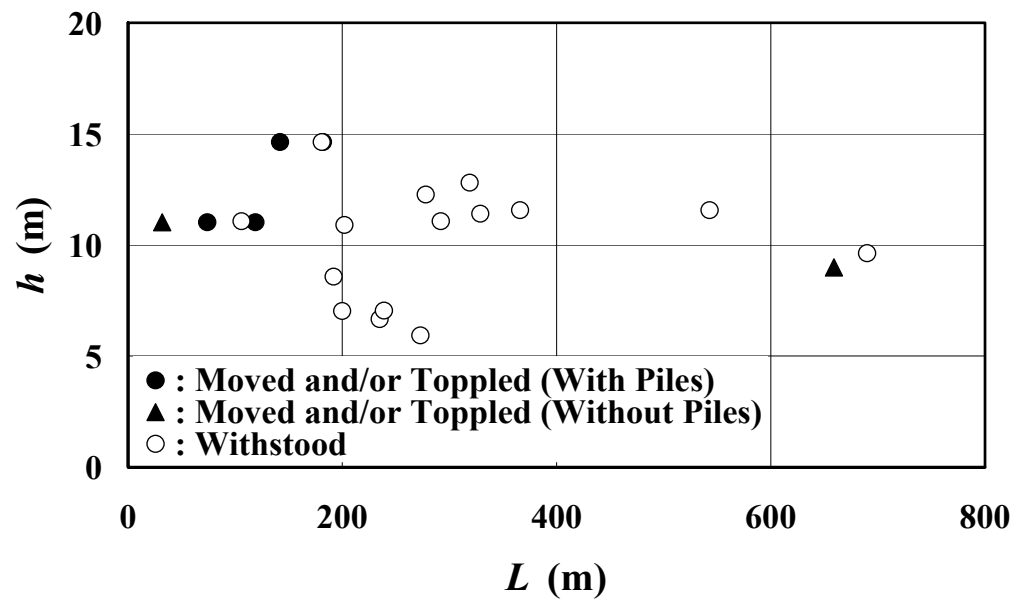

Figure 10. Relationship among the distance $L$ from the sea to RC building, inundation depth $h$ and damage type of the building. 


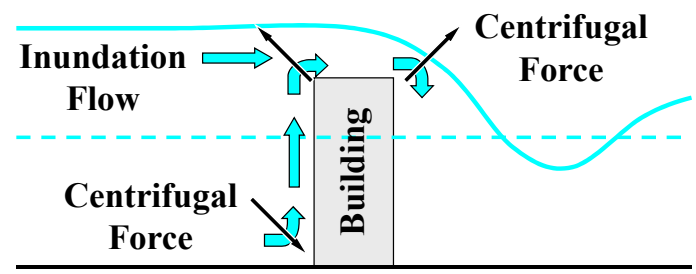

Figure 11. A schematic diagram of the centrifugal forces acting on on-shore building due to the overflowing tsunami.

if the depth is $21 \%$ of the building height, the submerged RC building is moved and/or toppled, 3 ) as the relative depth increases, the relative inundation depth which RC building is moved and/or toppled has a tendency to increase and 4) a difference is recognized between the relative inundation depths that $\mathrm{RC}$ buildings with and without foundation piles were moved and/or toppled.

Figure 10 shows a relationship among the distance $L$ from the sea to RC building, inundation depth $h$ and damage type of the building. Some of the distances in the figure are evaluated using the distance evaluation function of Google Earth. It is the judgment by limited data, but can be understood that $\mathrm{RC}$ buildings are moved and/or toppled regardless of the distance from the sea if inundation depth is large (deeper than $9 \mathrm{~m}$ in this tsunami) and $\mathrm{RC}$ buildings are submerged.

The moving and/or toppling of RC building depend on the fluid force of tsunami on it. There is an opinion on the fluid force that the wave pressure of a quasi-steady tsunami inundating on flat land is the hydrostatic pressure distribution [e.g. Asakura et al., 2000]. There is another opinion that as the dynamic pressure cannot be ignored, the wave pressure is the non-hydrostatic pressure distribution [Matsutomi, 2009b]. As one of the reasons of the non-hydrostatic pressure distribution, it is conceivable that the streamline with the diagonal downward convex part (the diagonal downward centrifugal force) in the lower front of the building is formed. When a huge tsunami as RC building is submerged overflows the roof or roof floor of the building, the formation of streamline with the diagonal upward convex part (the diagonal upward centrifugal force) in the upper front and back of the building would be related to the damage of the building. This schematic view is shown in Fig. 11.

\section{DAMAGE CONDITION TO COASTAL PINE TREE}

Damage conditions to coastal trees such as the lodging, uprooting and breaking are necessary to more accurately estimate the tsunami energy and force reductions due to coastal woods. The damage condition to coastal black pine tree is examined through both field surveys and field tests.

Figure 12 shows a relationship among the chest height diameter $D$ of coastal black pine tree, inundation depth $h$ and damage type (Lodging: $\odot$, Uprooting: $\Delta$, Breaking: $\diamond$, Withstanding: $\square$ ) of the tree. The figure indicates that 1) although the transition region where the damaged and the withstood were mingled is considerably large, both are relatively well classified by the chest height diameter and

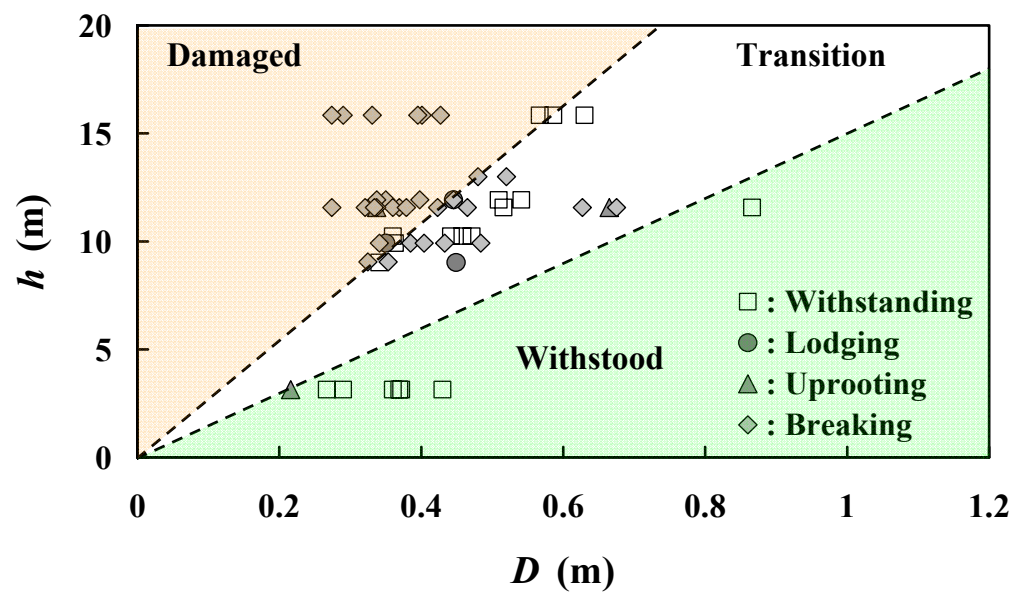

Figure 12. Relationship among the chest height diameter $D$, inundation depth $h$ and damage type of coastal black pine tree in the 2011 Tohoku Earthquake Tsunami. 
the inundation depth, 2) as the ratio of the inundation depth to the chest height diameter becomes large, a tendency of the breaking becomes strong, 3) it is the same in the case of evergreen tree Sea Casuarina (another name 'coastal pine') in Indonesia [Matsutomi et al., 2011] that the breaking data extend over both domains of the lodging and uprooting, and 4) the force at the uprooting tends to be smaller than that at the lodging. It is conceivable as the reasons of the result 4) that the main root which spreads laterally broke at a lodging stage besides the ground condition and ground water level.

The inundation height of the 2011 Tohoku Earthquake Tsunami on the Sanriku coast reached more than $15 \mathrm{~m}$ (The 2011 Tohoku Earthquake Tsunami Joint Survey Group, 2011). Besides, as there was not much depth of the coastal land area, and probably incident tsunami and reflected tsunami came and went in the same small coastal land area and/or tsunami stagnated, a remarkable difference between the inundation depths at the front and back of building was not recognized. Therefore, it is difficult to estimate the maximum incident tsunami component from the tsunami trace on the building wall surface. In this study, assuming that the inundation depth at the front of the building was caused by the maximum incident tsunami component, inundation flow velocity is estimated by the simple method proposed by Matsutomi [2009a], and then the drag force $F$ and moment $M$ acting on each coastal black pine tree are estimated using the estimated inundation flow velocity. The expressions adopted in this study to estimate the inundation flow velocity, drag force and moment are as follows:

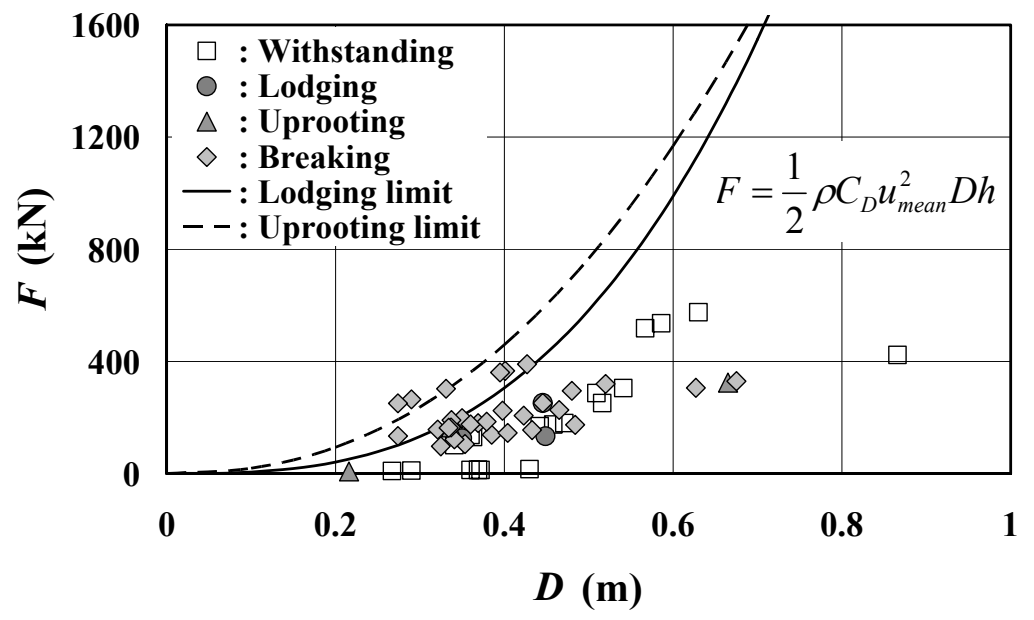

Figure 13. Relationship among the chest height diameter $D$, force $F$ and damage type of coastal black pine tree (field surveys).

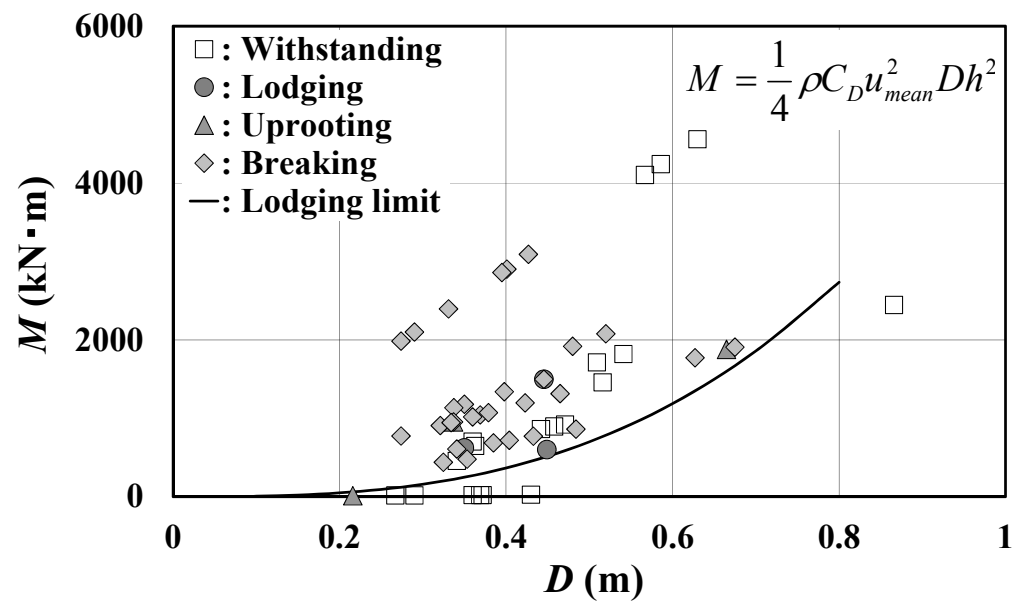

Figure 14. Relationship among the chest height diameter $D$, moment $M$ and damage type of coastal black pine tree (field surveys). 


$$
\begin{gathered}
u_{\text {mean }}=0.81 \sqrt{g h} \\
F=\frac{1}{2} \rho C_{D} u_{\text {mean }}^{2} D h \\
M=\frac{1}{4} \rho C_{D} u_{\text {mean }}^{2} D h^{2}
\end{gathered}
$$

where $g$ is the gravitational acceleration, $\rho$ the fluid density and $C_{D}$ the drag coefficient. The projection area of tree and moment acting on tree are estimated by the expressions $D h$ and $F h / 2$, respectively. $C_{D}=1.1$ is adopted.

Figure 13 shows a relationship among the chest height diameter $D$, drag force $F$ estimated by Eq. (2) and damage type of coastal black pine tree. Figure 14 shows a relationship among the chest height diameter $D$, moment $M$ estimated by Eq. (3) and damage type of the tree. In the figures, the upper limit conditions of the lodging (solid line) and uprooting (dotted line) obtained by a field test for the lived Sea Casuarina carried out on the west coast of Central Sumatra, Indonesia [Matsutomi et al., 2011] are also shown.

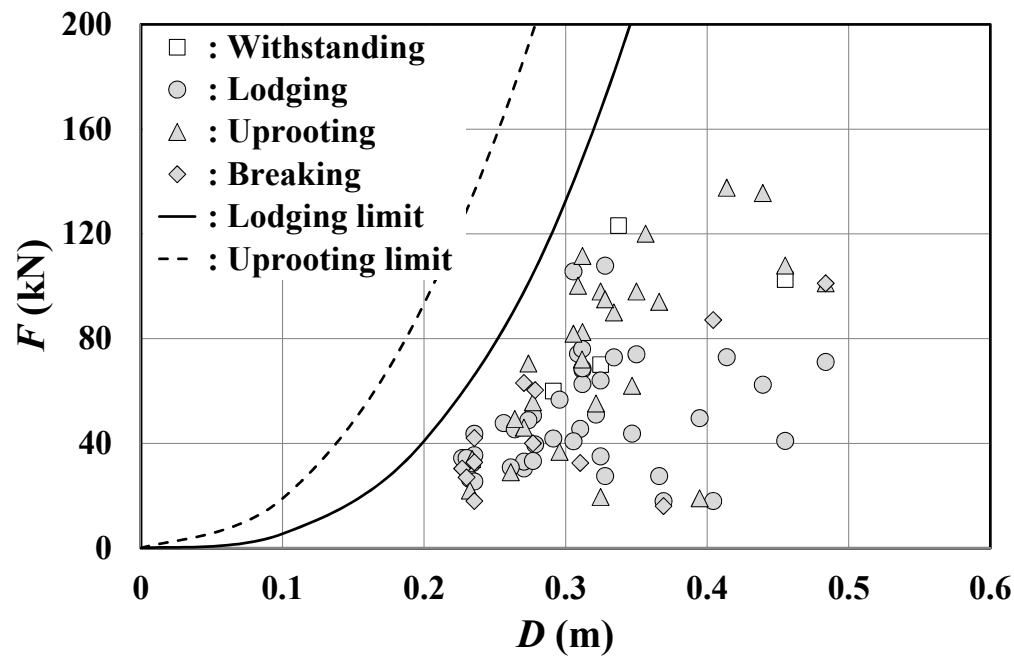

Figure 15. Relationship among the chest height diameter $D$, horizontal force $F$ and damage type of coastal black pine tree (field tests).

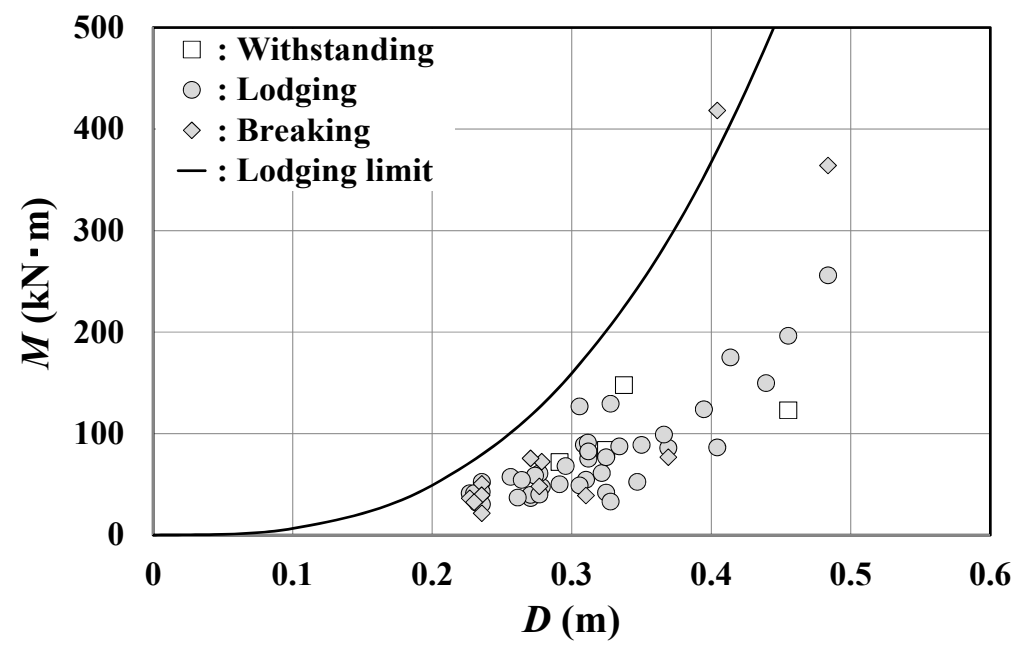

Figure 16. Relationship among the chest height diameter $D$, moment $M$ and damage type of coastal black pine tree (field tests). 
As will be seen from Fig. 13, at the viewpoint of the force, the field survey data have a tendency to be slightly smaller than the damage conditions of the upper limit for Sea Casuarina. On the other hand, at the viewpoint of the moment, the field survey data have a tendency to be larger than the damage conditions. The latter may be caused by the estimation method of the moment (Eq. (3)). Without distinction of Indonesia and Japan, the half of the inundation depth is adopted as the height from the ground to the point of action of the force in the field surveys, whereas the point of action of the force is fixed to the height of $1.2 \mathrm{~m}$ from the ground in the field tests. For your information, a lot of data of tree which broke at higher point than $1.2 \mathrm{~m}$ from the ground are included in the field survey data.

Figure 15 shows a relationship among the chest height diameter $D$, horizontal force $F$ and damage type of the tree. Figure 16 shows a relationship among the chest height diameter $D$, moment $M$ and damage type of the tree. These are based on the field tests on the Taro and the Yamada coasts. In the figures, the upper limit conditions of the lodging and uprooting obtained by the field test for Sea Casuarina are also shown. It is the same as the case of Sea Casuarina that the breaking data extend over both domains of the lodging and uprooting. It is not sure for reasons of the withered trees and ground condition, the force to withstand of coastal black pine tree is weaker than that of Sea Casuarina. This is the same tendency as Fig. 13 and supports the adoption of the inundation flow velocity of Eq. (1) in the estimation of the drag force based on the inundation depth. Although the force to withstand the uprooting $>$ the force to withstand the lodging is on the average, the upper limit of the force to withstand every the chest height diameter is almost the same in any damage type. As the field survey results shown in Figs. 12-14, the force of the uprooting is sometimes smaller than that of the lodging.

\section{EFFECTS AND LIMITS OF COASTAL WOODS}

\section{Tsunami on the Sendai Coast}

Because of a huge tsunami, the effects of coastal woods on reducing the tsunami energy and force could not be confirmed in many coastal woods, but those were recognized on the Sendai coast.

Figure 17 shows examples of the ground height distribution after the 2011 Tohoku Earthquake and inundation height distribution of the 2011 Tohoku Earthquake Tsunami from the shoreline to Teizan canal on the Sendai coast, where the ground height and inundation height $Z$ are from the datum level (DL). Except for Gamo purification center, the inundation depth $h$ (= inundation height - ground height) was around 3-6 m.

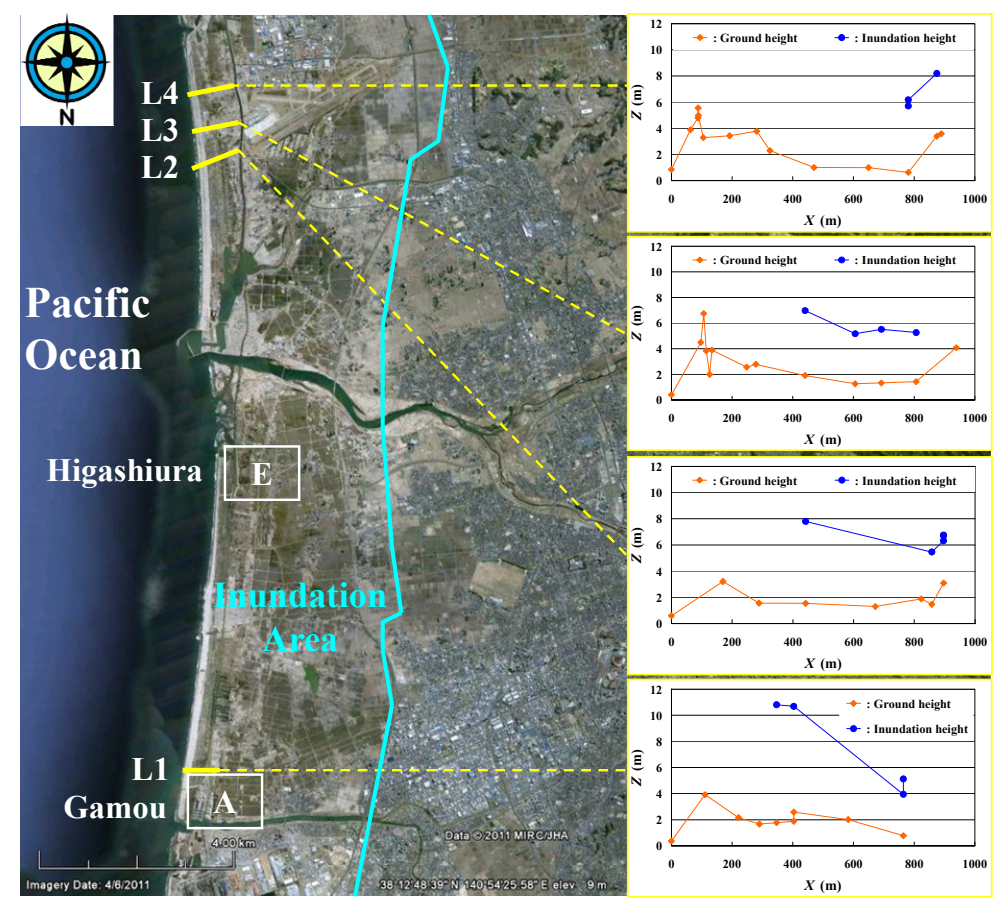

Figure 17. Examples of the ground height distribution after the 2011 Tohoku Earthquake and inundation height distribution of the 2011 Tohoku Earthquake Tsunami from the shoreline to Teizan canal on the Sendai coast (above DL). (Google Earth) 


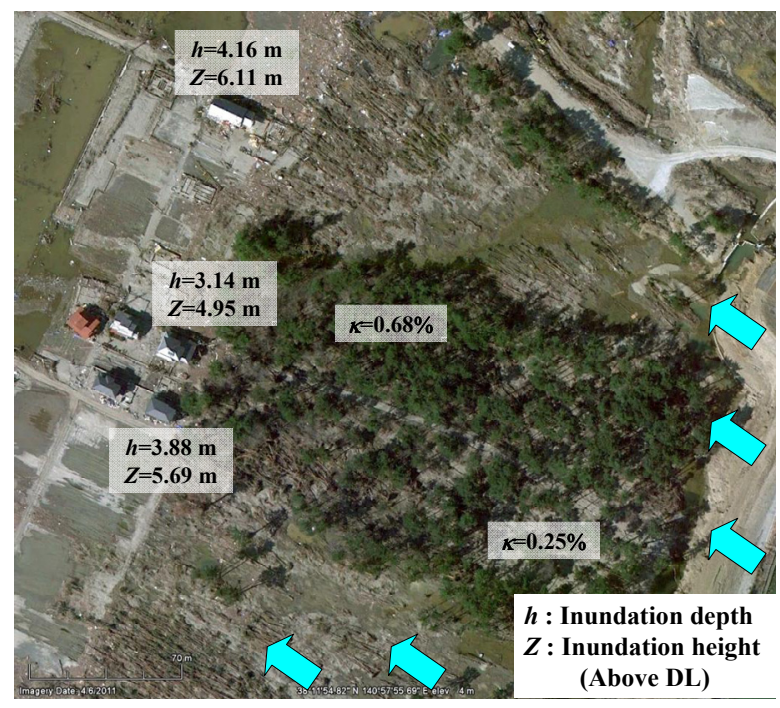

(a) After the tsunami suffering $\left(L_{c w}=140 \mathrm{~m}, W_{c w}=220 \mathrm{~m}\right)$

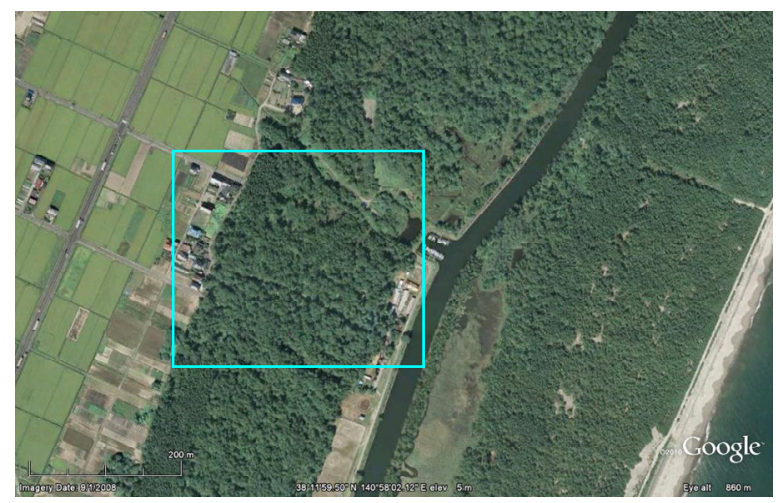

(b) Before the tsunami suffering ((a) is the rectangle part)

Figure 18. Effects and limits of coastal woods which consist of mainly coastal black pine trees in Higashiura on the Sendai coast. (Google Earth)

\section{Effects and Limits of Coastal Woods}

The effects of coastal woods on reducing the tsunami energy and force have been pointed out for a long time. Figure 18 shows one of the examples of the effects of coastal woods which mainly consist of coastal black pine trees in Higashiura on the Sendai coast (see Fig. 17), where $\kappa$ defined by Matsutomi et al. [2007] is the mean tree density (\%) of coastal woods estimated using the diameter of tree trunk at the chest height, $L_{C W}$ the length of coastal woods area parallel to the shoreline and $W_{C W}$ the width of coastal woods area perpendicular to the shoreline. Figure 18(b) shows the situation of the coastal woods before the tsunami suffering. It is unknown when a part of the coastal woods suffered the damage for the lodging, uprooting and breaking. It can be understood from the figure that both the inundation depth $h$ and inundation height $Z$ were reduced by around $1 \mathrm{~m}$ $(25 \%)$ just behind the area where coastal trees survived. However, it is necessary to note that even if the depth of the coastal woods is around $220 \mathrm{~m}$, those reduction are at most $25 \%$. Coastal woods cannot be expected to largely reduce the tsunami energy and force.

\section{CONCLUSIONS}

Main results in this study are that:

- There were no moved and/or toppled RC buildings with 5-stories and over in this tsunami. Japanese RC buildings could withstand when those were not submerged at the maximum inundation depth of the tsunami.

- The submerged vertical section area $A_{C}$ of RC building in the tsunami inundation flow direction is a good parameter to judge whether the buildings are moved and/or toppled. 
- The aperture ratio $O_{p}$ of actual RC building is less than around $38 \%$, and the aperture ratio of the withstood building in spite of the submergence was greater than $17 \%$.

- As the relative depth $h_{B} / H$ of foundation part under the ground increases, the relative inundation depth $h / H$ which RC building was moved and/or toppled has a tendency to increase.

-A relationship among the chest height diameter $D$ of coastal black pine tree, inundation depth $h$ and damage type of the tree was presented, and its validity and availability were examined through comparing the field survey data, transformed into the drag force or the moment instead of the inundation depth, with the field test data.

-Equation (1) is effective in the simple estimation of the tsunami inundation flow velocity on a flat land.

- The field test data at the viewpoint of force were considerably greatly scattered. Although a little difference is recognized between the damage conditions of each damage type at the viewpoint of force (the force to withstand the uprooting $>$ the force to withstand the lodging on the average), the universal expression of the damage condition is difficult.

- Effects and limits of coastal woods mainly consisted of coastal black pine trees on reducing the tsunami energy and force were confirmed on the Sendai coast.

\section{ACKNOWLEDGMENTS}

This work was supported by the Grant-in-Aid for Scientific Research from the Japan Society for the Promotion of Science (No. 21510187 and No. 24510244), the North Tohoku universities of Akita, Hirosaki and Iwate and the Science and Technology Research Partnership for Sustainable Development from the Japan Science and Technology Agency, the Japan International Cooperation Agency, the State Ministry of Research and Technology of Indonesia and the Indonesian Institute of Science. Iwate prefectural government is also appreciated for the permission and cooperation of implementing the field tests on the damage type and damage condition of coastal black pine tree.

\section{REFERENCES}

Abe, K. 2011. $M_{t}$ is 9.1 even in the estimation from the mean run-up height, A report contributed to the tsunami bulletin board in Japan on May $5^{\text {th }}$ 2011. (J)

Asakura, R., K. Iwase, T. Ikeya, M. Takao, T. Kaneto, N. Fujii and M. Omori. 2000. An experimental study on wave force acting on on-shore structures due to overflowing tsunamis, Proceedings of Coastal Engineering, JSCE, Vol.47, 911-915. (J)

JMA. 2011. On the 2011 Off the Pacific Coast of Tohoku Earthquake Tsunami (15 $5^{\text {th }}$ report), http:// www.jma.go.jp/jma/press/1103/13b/kaisetsu201103131255.pdf, 2011-3-14 referred. (J)

Matsutomi, H., K. Ohnuma, A. Suzuki and K. Imai. 2007. Governing equations for inundated flow in vegetated area and similarity law for tree trunk, Proceedings of $30^{\text {th }}$ International Conference on Coastal Engineering, ASCE, 1638-1650.

Matsutomi, H. 2009a. Problems in the recent onshore and land tsunamis, Lecture Notes of the $45^{\text {th }}$ Summer Seminar on Hydraulic Engineering, 2009, Course B, JSCE, B-3-1-20. (J)

Matsutomi, H. 2009b. Contribution of dynamic pressure to fluid force and probability distribution of collision force of floating objects due to tsunami inundated flow, J. of JSCE, Ser. B2 (Coastal Eng.), Vol. 65, No. 1, 836-840. (J)

Matsutomi, H., K. Harada, A. B. Widagdo and S. Diposaptono. 2011. Field Test on the Lodging and Uprooting Conditions of Casuarinas and Verification of Those through the 2010 Mentawai Earthquake Tsunami, J. of JSCE, Ser. B2 (Coastal Eng.), Vol. 67, No. 2, 301-305. (J)

The 2011 Tohoku Earthquake Tsunami Joint Survey Group. 2011. Nationwide Field Survey of the 2011 Off the Pacific Coast of Tohoku Earthquake Tsunami, J. of JSCE, Ser. B2 (Coastal Eng.), Vol. 67, No. 1, 63-66. 